\title{
CTSS wt Allele
}

National Cancer Institute

\section{Source}

National Cancer Institute. CTSS wt Allele. NCI Thesaurus. Code C103235.

Human CTSS wild-type allele is located in the vicinity of $1 \mathrm{q} 21$ and is approximately $36 \mathrm{~kb}$ in length. This allele, which encodes cathepsin S protein, plays a role in antigen processing. 